\title{
GEOLOGICAL 3D STATIC MODEL OF BAHARIYA FORMATION (UPPER ALBIAN- CENOMANIAN), SHAHD/SHAHD SE FIELDS, NORTHERN WESTERN DESERT, EGYPT
}

\author{
Mostafa M. M. ${ }^{1}$, Fahmy M. ${ }^{1}$, Darwish M. ${ }^{2}$
}

1enap Sipetrol, Egypt. 2Cairo University, Faculty of Science, Geology Department.

\begin{abstract}
In 2005, the importance of East Tiba Sub-Basin was highlighted since the oil was commercially discovered for the first time in the Upper Albian Lower Bahariya sandstones.

All the used available subsurface data including cores, sedimentary structures, lithological characters, wireline logs signature, petrophysical parameters and biostratigraphy have revealed that, the Lower Bahariya reservoir sandstones are represented by three main stacked tidal channels that were deposited in marginal marine possible tidal-dominated estuary depositional environment.

A regional conceptual depositional model has been constructed covering the development leases and surrounding areas to understand the distribution of the sandy facies, their own petrophysical characters and related production behaviour. The model explained the inter-tonguing relations between the relatively low sand qualities (distal facies), less oil productive reservoir sands of the Shebl area sands and the good quality (proximal facies), more oil productive reservoir sands of the SE located marginal marine tidal channels of Shahd/Shahd SE Fields.

A 3D reprocessed PSDM seismic cube has been used in addition to the well data to produce the Bahariya structure map as it represents a good seismic marker allover the study area. The play concept in the study area is a three- way dip closure along NW trending Cretaceous faults having enough throw (+/$600 \mathrm{ft}$.) to bring the Abu Roash "G" shales in the down-thrown side to juxtapose the Lower Bahariya reservoir sands in the up-thrown side.
\end{abstract}

Keywords: Shahd/Shahd SE fields, East Tiba Sub-Basin, Lower Bahariya sandstone reservoirs, and 3D geological static model.

\section{INTRODUCTION}

The study area is around $51 \mathrm{Km}^{2}$ being located along the SW flank of East Tiba Sub-Basin depocenter

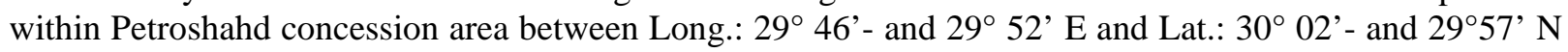
(Fig. 1).in East Tiba Sub-Basin led to the formation of the Joint venture PetroShahd Company in 2008, to operate seven discovered development leases namely Shahd, Shahd SE, Diaa, Ghard, Rana, Shebl and Alzahraa development leases (Fig. 1).

The aim of the present work is to highlight the importance of the integrated approach for building a reliable 3D geological model for the Lower Bahariya Sandstone reservoir in the Shahd/Shahd SE field areas. This will be the basic static model as the input data for building the dynamic reservoir model and its future management plans.

The available subsurface data include the lithologic aspects and biostratigraphic results of the study sequences picked up from the conventional cores and ditch cuttings that supported by the wireline log signatures. The petrophysical data and the 3D seismic interpretations are considered and included in order to complete building the static model (i.e. geological/geophysical and engineering integrated task). 
Mostafa et al.

Fig. 1: Shahd/Shahd SE Fields Location Map

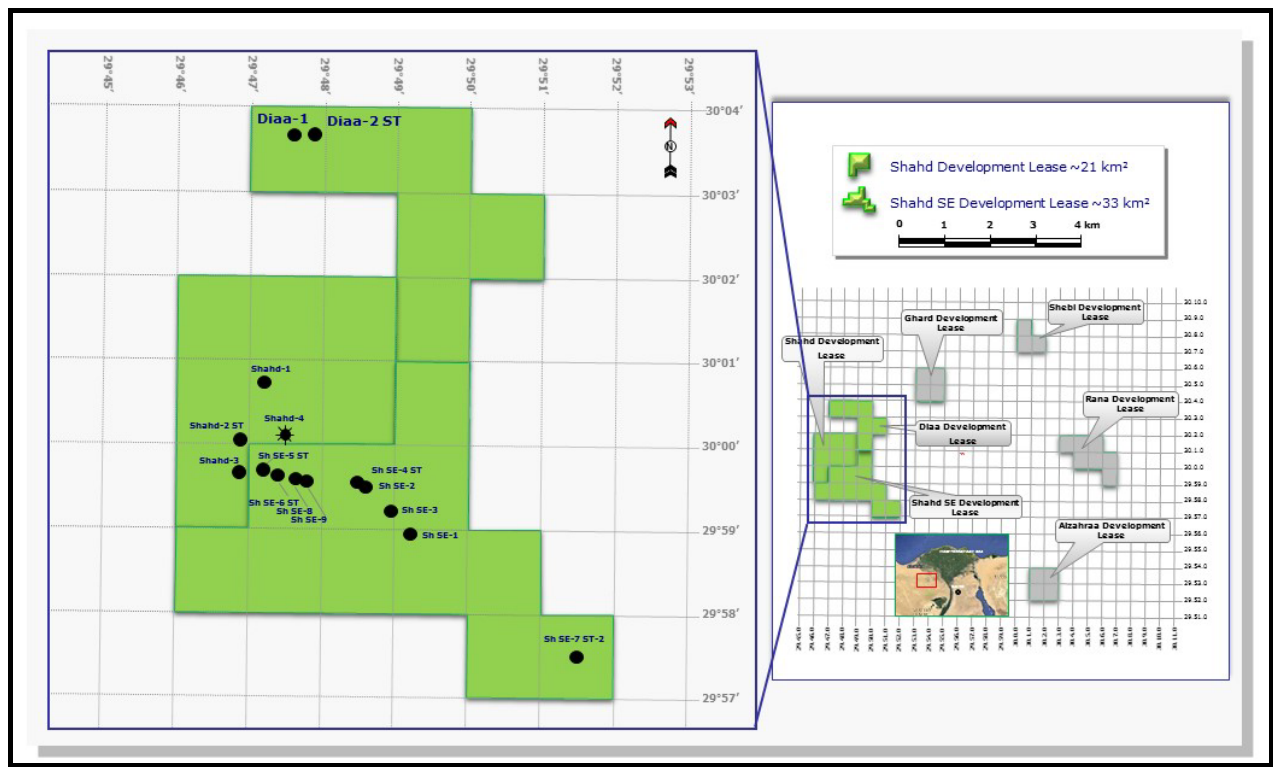

The Bahariya Formation as a main oil reservoir in the North Western Desert basins (Fig. 2) in general and specially Abu Gharadig Basin, had been analysed by eminent workers and studies in order to highlight its stratigraphic, sedimentologic and hydrocarbon prospect. Of mention the works of Norton, (1967), Sestini, (1984), Barakat et al., (1987), Said, (1990), Taha, (1992), Hegazy, (1992), Darwish, (1994), Geizery et al., (1998), Mahmoud and Barkooky, (1998), Keeley and Massoud, (1998), Moustafa et al., (1998), Dolson et al., (2000), Darwish and Tawfik, (2008) and Tassy et al., (2015). These studies form the basic background for the evaluation purposes of the present work.

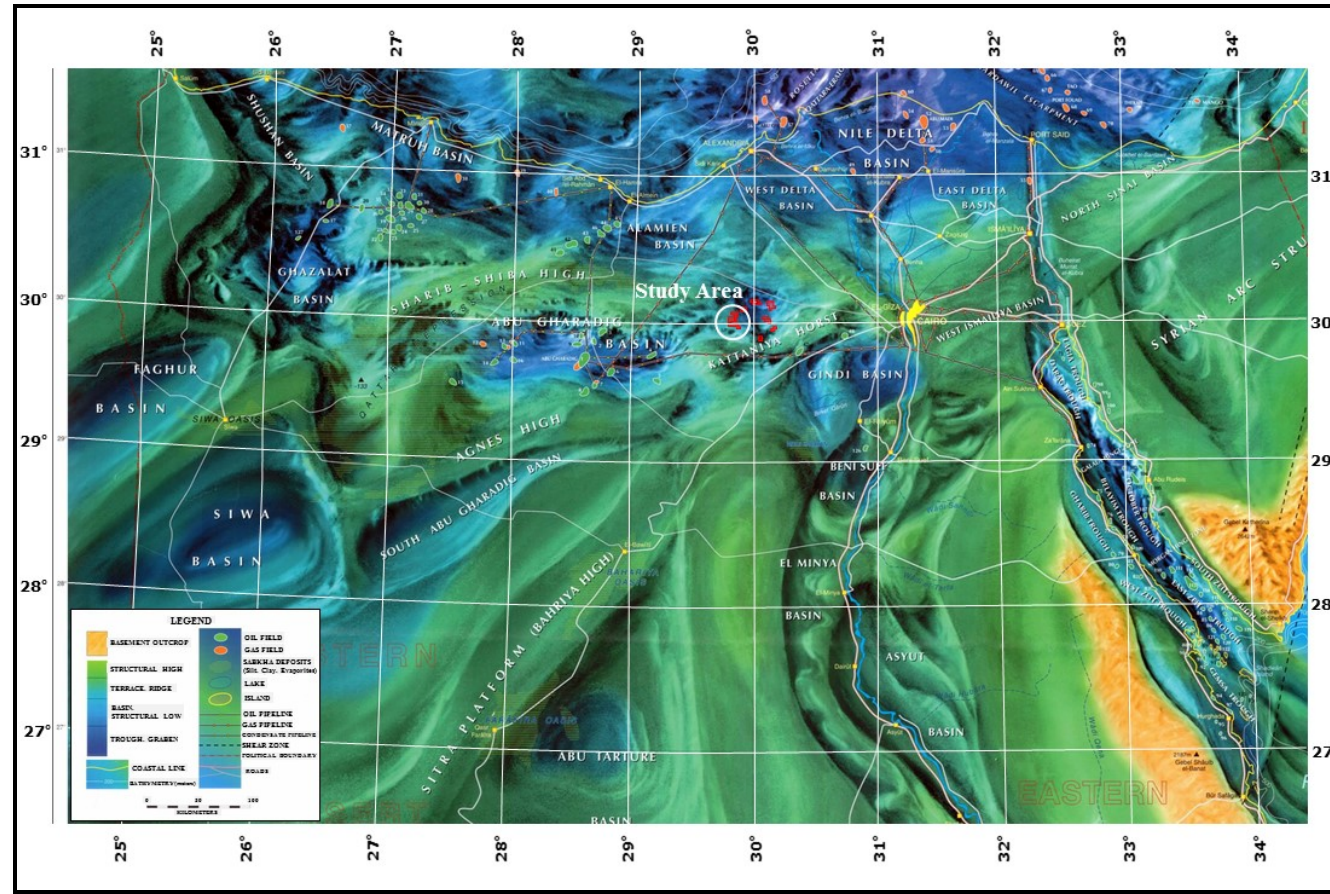

Fig. 2: Regional

Sedimentary

Basins, north

Western Desert

(PGS, 2001)

STRATIGRAPHIC SETTING

The penetrated stratigraphic sequences are represented by the Phanerozoic sedimentary units that rest on the Precambrian basement rocks (Fig. 3). These basement rocks are unconformably overlain by the oldest well identified sandstone sequences of Early Jurassic age (Ras Qattara Formation). The Jurassic sequences include the carbonate/shale sequences with thin sandstone interbeds of Wadi El Natrun, Khatatba and 


\section{Geological 3D static model of Bahariya formation}

Masajid formations from base to top. These are unconformably overlain by the Lower Cretaceous sandstone-dominated Alam El Bueib, Alamein, Dahab and Kharita formations. It is worth to mention that in the study field areas the Aptian Alamein Formation that overlained by Dahab shales are absent, most probably due to erosion and/or non-deposition. The main first vast marine transgressive systems on the non-marine clastics of the lower to middle Albian Kharita sandstones are represented by the Bahariya Formation (Upper Albian-Lower Cenomanian) that followed upwards by the carbonate/shale sequences of Abu Roash Formation (Late Cenomanian-Santonian). These are unconformably overlain by the open marine chalk of Khoman Formation. The Tertiary sequences of clastic/carbonate-dominated facies are represented by the Paleocene-Eocene Apollonia Formation that unconformably overlie the Maastrichtian Chalks. These are followed upwards by the Oligocene Dabaa Formation. The topmost sequence is the clastic-dominated Moghra Formation of Early Miocene age (Fig. 3).

Fig. 3: Generalized Litho- Stratigraphic Column of the Study Area.

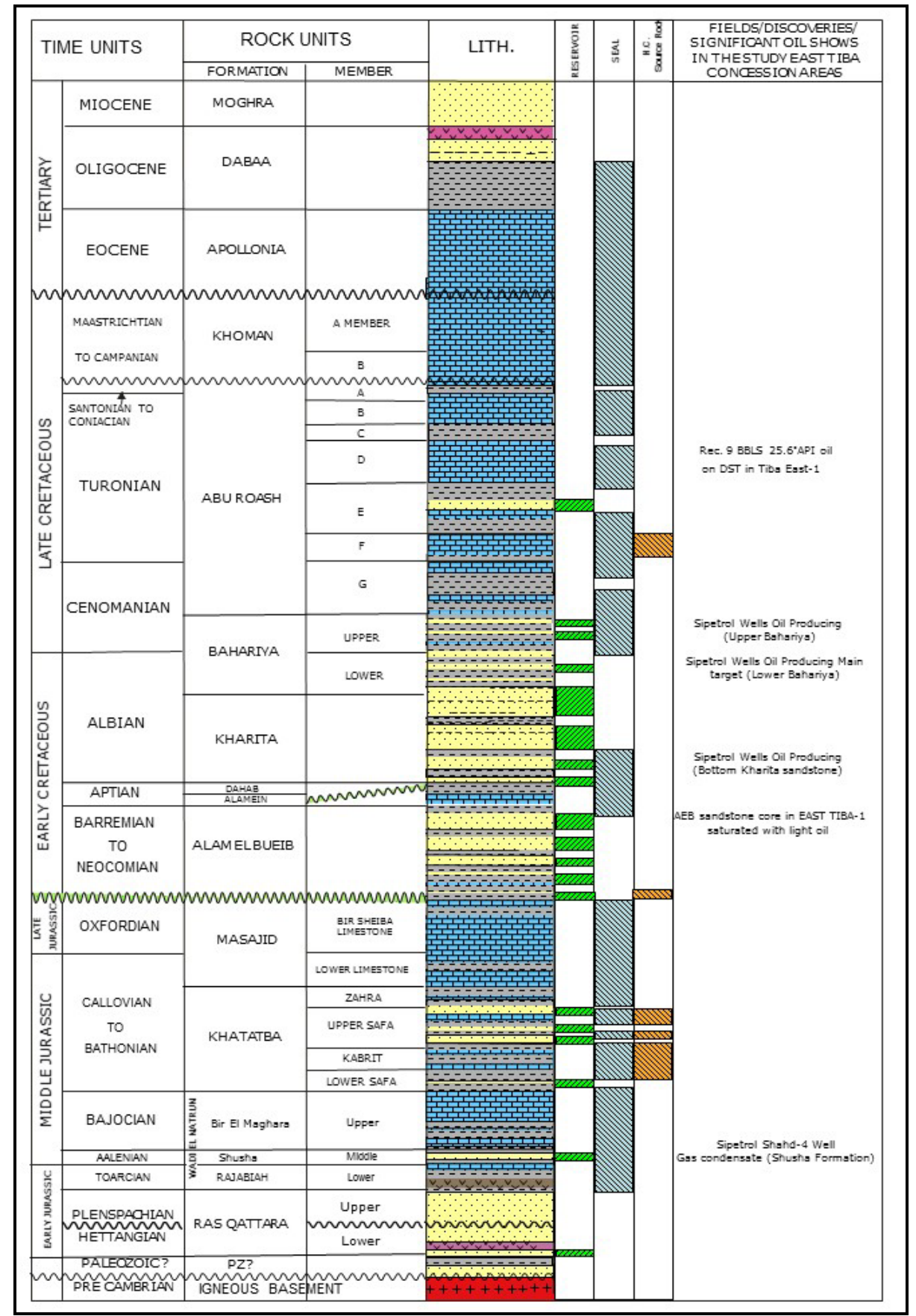


Mostafa et al.

Since the work of Ball and Beadnell (1903) that was followed by Stromer (1914), Lebling (1919) and Blanckenhorn (1921), the thick clastic section of Early Cenomanian age was assigned to Bahariya Formation that exposed along the floor of the Bahariya depression at Gebel El Dist. According to Dominik (1985) and Said (1990), the surface section of the formation was assigned to Upper Cenomanian age. However, the detailed biostratigraphic analyses and interpretation of the clastic-dominated sequences that overly the massive sandstones of Kharita Formation, assigned this formation to the Late Albian-Early Cenomanian age (Schlumberger, 1984, Abdel Kireem et al., 1996, Nemec, 1996). The Bahariya-1 well is the type well for the subsurface Bahariya Formation (Norton, 1967). The unit acts as the main producing horizons in most of the oil fields of the North Western Desert basins (e.g. Abu Gharadig, Badr El Din, Meleiha, Razzak, Qarun, Ahram, East Bahariya, Abu Sannan, East Tiba fields, etc.).

In the study field areas, The Bahariya Formation underlies the Abu Roash "G" member of Late Cenomanian age and overlies the Kharita Sandstones of Early to Middle Albian age (Fig.3). It can be subdivided into Upper and Lower members based on the lithologic as well as biostratigraphic and wireline logs support. The Lower Bahariya is clastic-dominated of Late Albian age being palynologically dated (Matonisporites phlebopteroids zone), while the Upper Bahariya is composed of mixed lithologies of shales, sandstones and carbonates of Early Cenomanian age (Elatosporites-palynozone).

In the East Tiba study area, the detailed stratigraphic setting was studied and analyzed through the subsurface data obtained from selected wells (Fig. 3). The stratigraphic examination and evaluation of these wells were principally focused on the nature of the encountered lithology, formation boundaries, thickness variations and fossil content.

\section{BIOSTRATIGRAPHIC ANALYSIS OF SHAHD-1 WELL}

Shahd-1 well interval (9900 to 11000' MD) had been paleontologically analyzed (foraminifera and palynology). Figure (4) is summarizing the biostratigraphic data in the mentioned well; the fossil content proved that, the Lower Bahariya member is of Late Albian to Early Cenomanian age and was deposited in a marginal marine setting, while the underlying Kharita Formation was deposited in a non-marine environment, most probably of fluvial domain.

Fig. 4:

Biostratigraphic

Data Summary

of Bahariya and

Kharita

formations in the study.

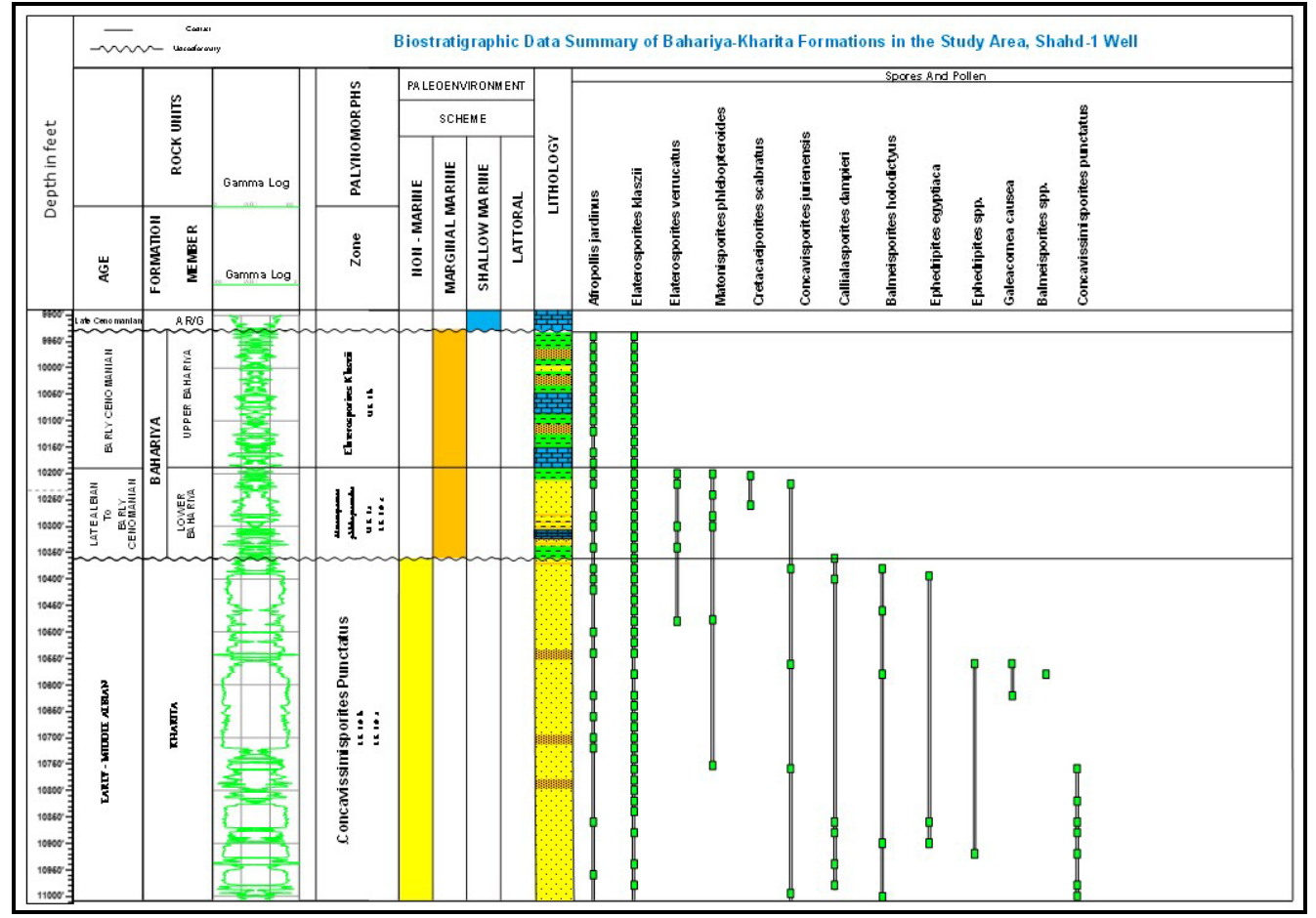

The biostratigraphic and palynological data of well Shahd-1 can be summarized as follows: 


\section{Geological 3D static model of Bahariya formation}

1. The contact between the Upper Bahariya and the overlying Abu Roash " $G$ " member is an unconformity due to the time missing of some index fossils supported by the abrupt change from marginal marine to shallow marine depositional regime.

2. The contact between the Lower and Upper Bahariya members is a normal contact without any considerable break in sedimentation.

3. The contact between Lower Bahariya Member and the underlying Kharita Fm. is represented by unconformity representing a time gap proved by the abrupt change from a non-marine fluvial Kharita sandstone to the marginal marine Lower Bahariya sandstone, that supported by the variation in dip regime.

4. The Lower Bahariya facies is marked by the presence of the first downhole occurrence of some index fossils such as Elaterosporites verrucatus, Matonisporites phlebopteroides and Cretacaeiporites scabratus that represent the Concavissimisporites punctatus palynozone (Fig. 4).

\section{STRUCTURAL SETTING}

The structural pattern at Bahariya level, based on the detailed seismic 3D interpretation of the study field areas are interpreted as a NW-SE trending horst block. This Shahd SE block is structurally 650' higher than the structure of Shahd-1 block that located toward the north (Fig. 5).

The crest of this horst block, as indicated by the structural depth map (Fig. 6) is located along the southern bounding fault with a NE gentle dip. The main bounding NW-SE fault of the horst block is dated Late Cretaceous as a result of the dextral shear tectonics that dominated Northern Western Desert province during the Late Cretaceous time.

\section{DEPOSITIONAL ENVIRONMENT}

According to Said (1990) the lower part of Bahariya Formation shows facies changes over the northern Western Desert, Egypt. Being dominated by a marginal marine to the north while in the south is of fluviomarine domains.

The Lower Bahariya cored intervals cut in well Shahd SE-5 (83') showed a moderate to good reservoir porosity and permeability of mature sand texture (sorting and packing). The presence of herring bone, cross bedding with mud drapes in bundles as well as the well sorted fine-grained quartz-arenite sandstone are the main features in the core that confirm the tidal channel environment. The detailed mineralogic and textural aspects of the (85') cored intervals in Shahd SE-5 well are shown in figure (7).

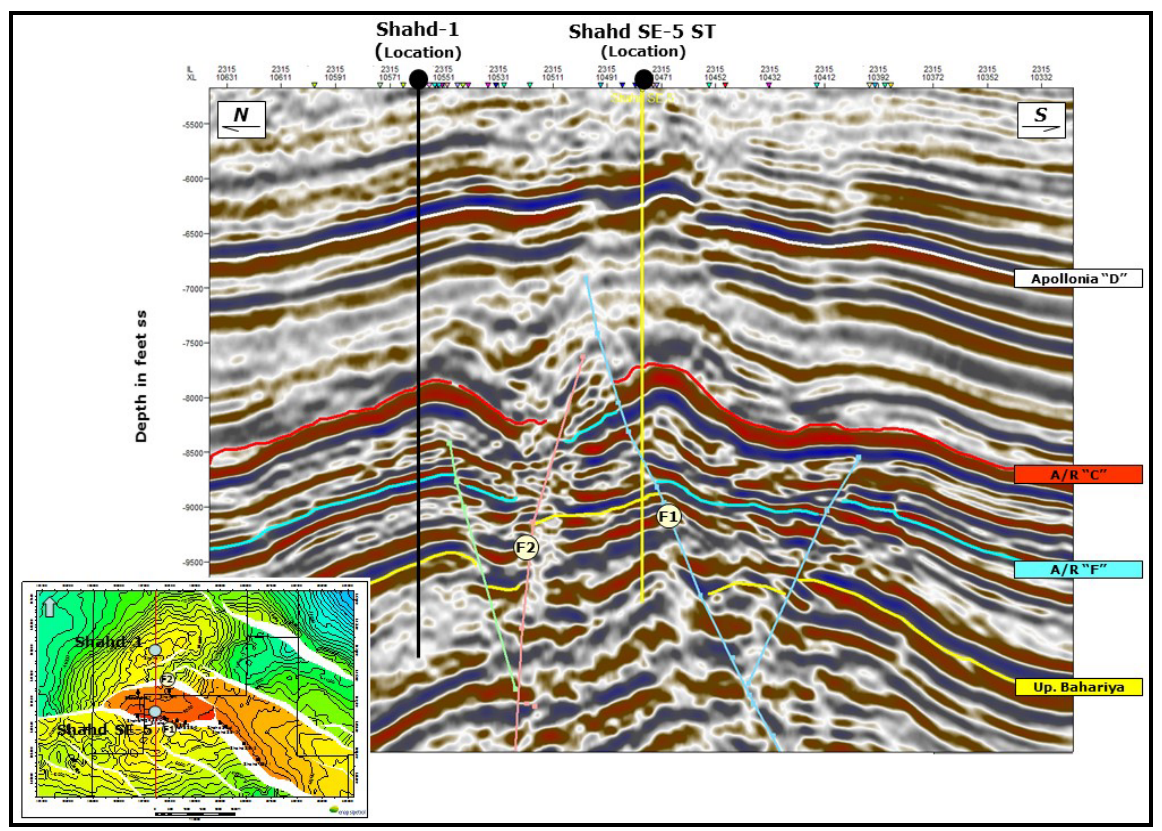

Fig. 5: Inline over Shahd SE-5 
Mostafa et al.

Fig. 6: Shahd/Shahd SE Fields Bahariya Structure Depth Map

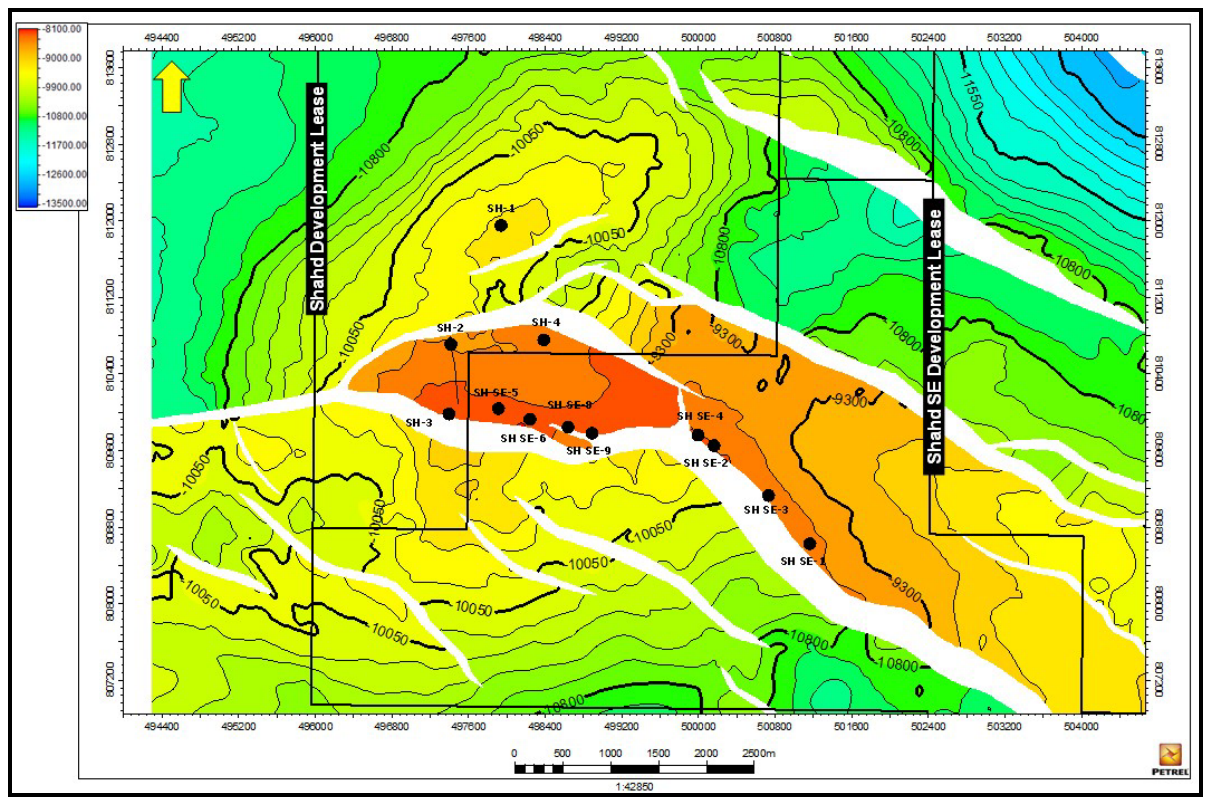

In the present study area, based on the Shahd SE-5 conventional core data (Corex, 2012), sedimentological study of the sandstone is interpreted as tidal channels deposited in possible tidal dominated estuary (Figs. 7 and 8).The interpretation of the paleo-depositional environment in which the sediments of the Lower Bahariya member have accumulated during the Late Albian time is based on the core data that indicate the marine origin of these sandstones during transgressive system tract(s) (TST), supported by the wireline log interpretations. The absence of wave dominated estuary criteria (barrier bars) indications from the well log correlation may support the tide-dominated estuary system.

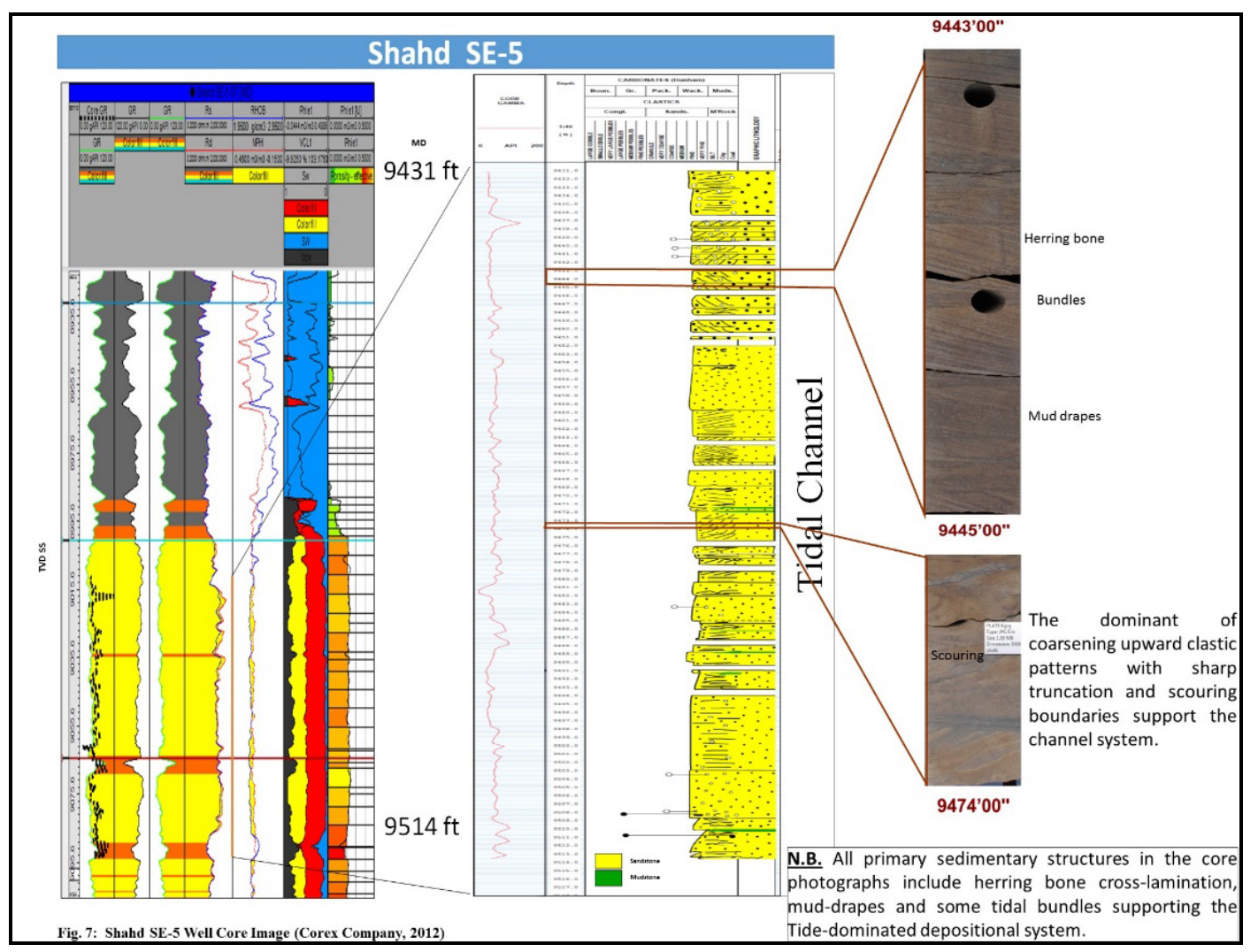

Fig. 7: Shahd SE-5 Core Image (Corex Report, 2012) 


\section{Geological 3D static model of Bahariya formation}

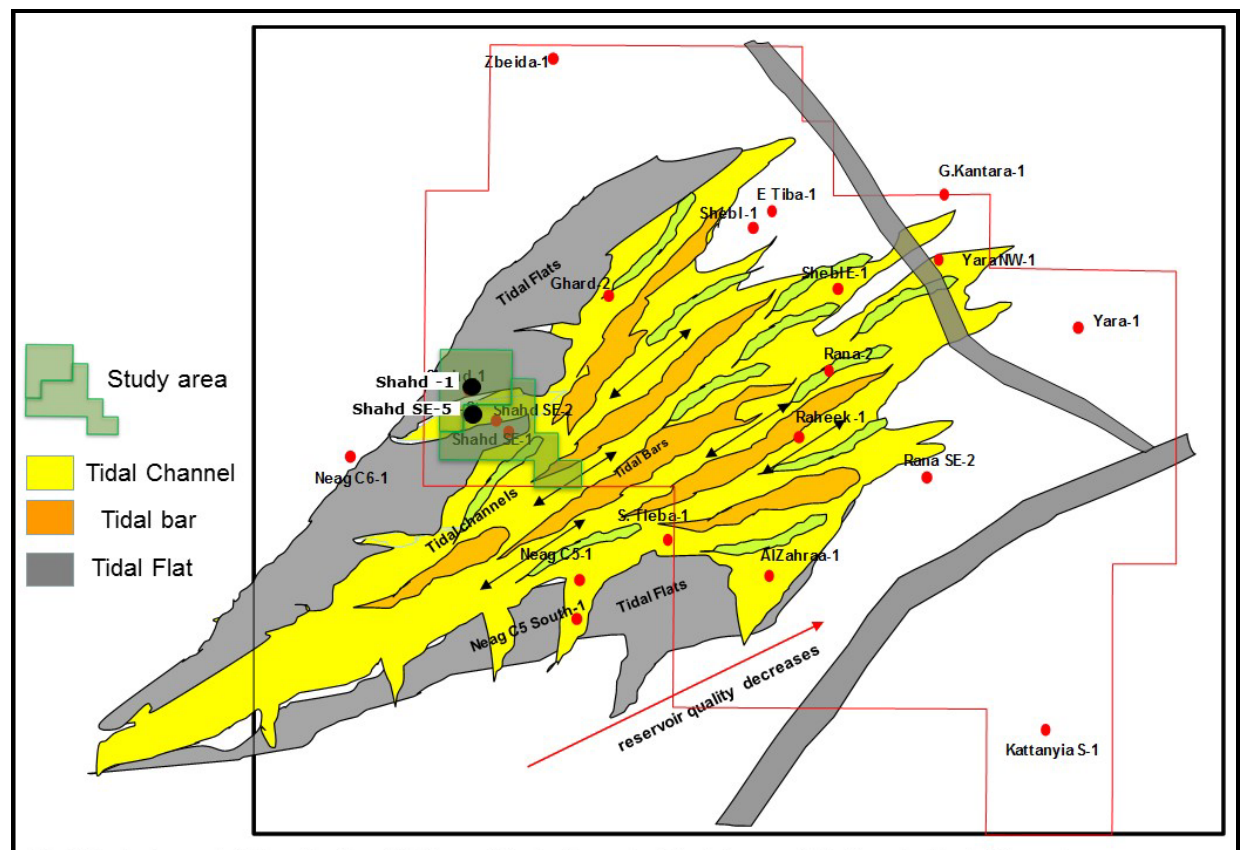

Fig. 8: Regional

Conceptual

Depositional

Model of Lower

Bahariya

Sandstone of the

Study Area

\section{GEOLOGICAL 3D STATIC MODEL}

Six steps as a workflow are used in order to establish the reservoir simulation 3D modeling. These steps are summarized as follow (Fig. 9):

Fig. 9: Wadi El Natrun (WEN)

Formation Stratigraphic Correlation, (Present Study)

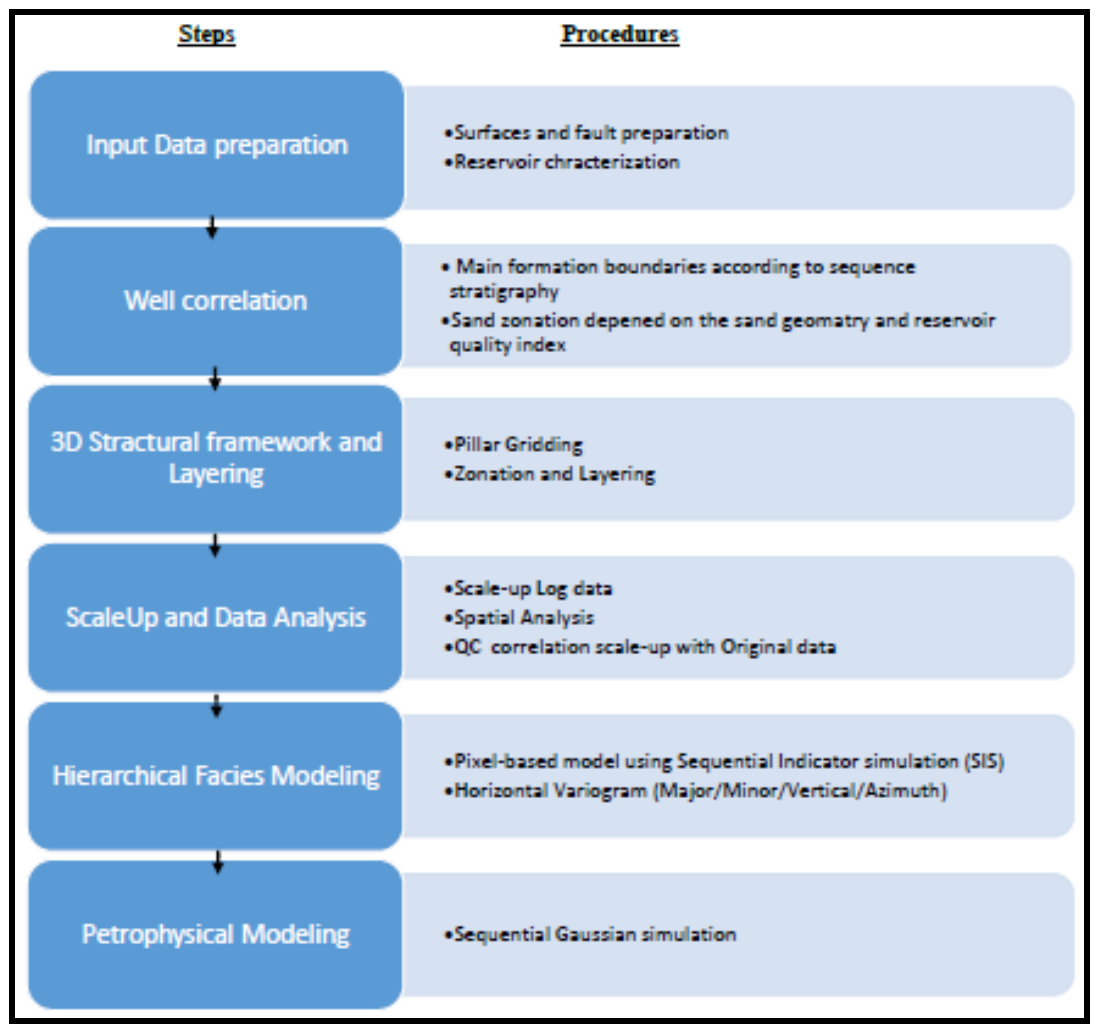

\section{1- Data input}

The types of data integrated within a 3D model depend on data availability, density, and distribution, as well as project objectives and working scale. The methodology presented here is well suited for various 
Mostafa et al.

working scales. It is particularly suited and most useful for regional synthesis to construct structural and stratigraphic relationships of the study area (Shahd/Shahd SE fields).

For a development plan, the following data are useful:

- Well survey data (X/Y location, well path) of 13 wells in Shahd / Shahd SE development lease.

- Well log data includes gamma ray mirror image, resistivity Rs/Rd, micro-resistivity MSFL, density/neutron, Vclay/porosity/water saturation.

- 3D Seismic Interpretation and Bahariya Depth Structure map.

- Core data of well Shahd SE-5 ST (Fig. 7).

- Biostratigraphic data from well Shahd-1 (Fig. 4).

- Main lithological and stratigraphic horizons (boundaries) in this study, Upper Bahariya, Lower Bahariya and Kharita formations.

- Fault surfaces, planar and linear structural measurements.

\section{2- Well log correlation}

The well log correlation of the selected 13 wells in Shahd/ Shahd SE development leases has been corrected based on sequence stratigraphy concept unconformities, truncations and depositional shifts (Fig. 10). The vertical and lateral variations in the sandy units of the Lower Bahariya member (Early Cenomanian- Late Albian) show that each unit has its own reservoir petrophysical parameters. The Lower Bahariya interval has been subdivided into 16 units representing the tidal channel environment in possible tidal dominated estuary, as the main task of the present study is to highlight the Upper Albian-Lower Cenomanian sequences in the study half graben.

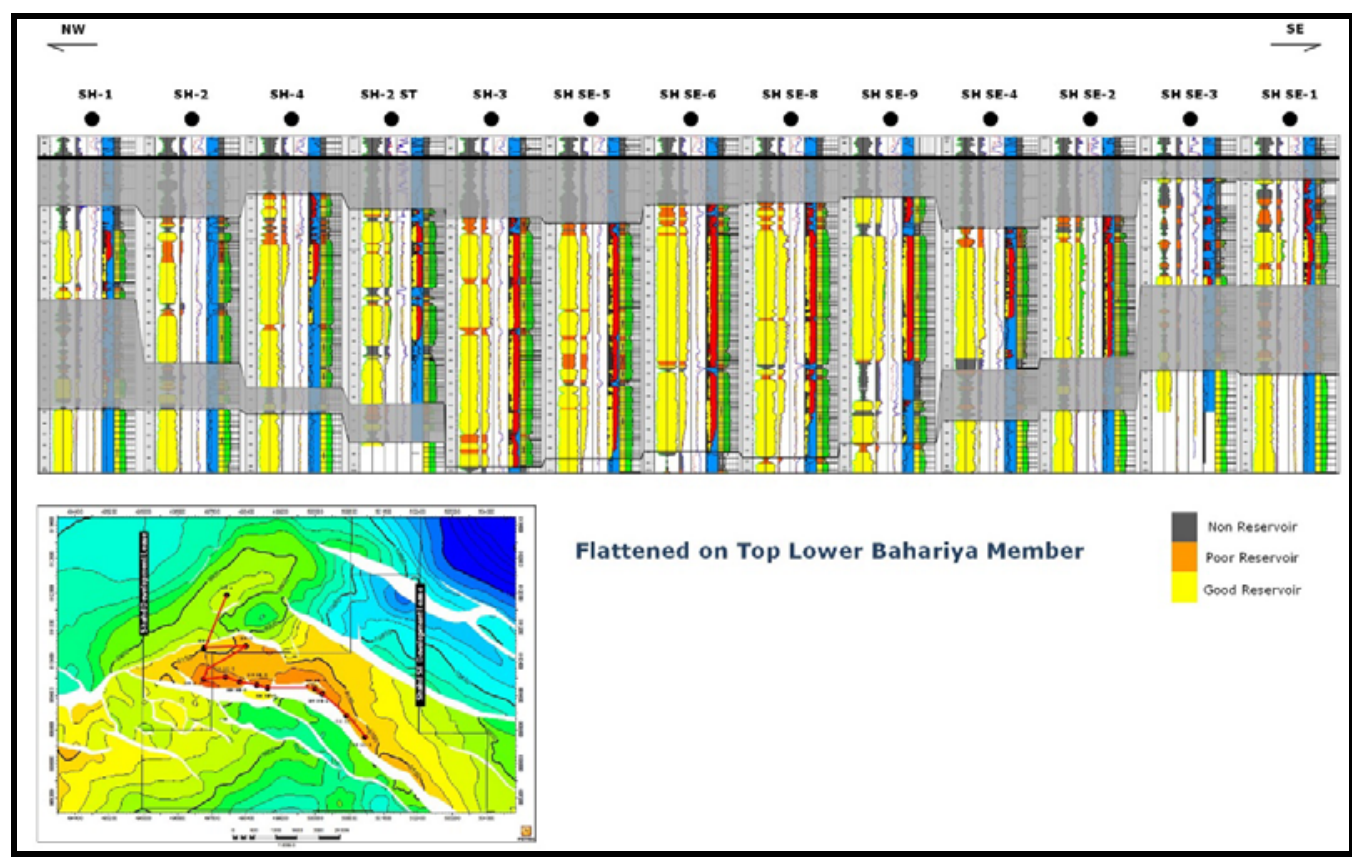

Fig. 10: Lower Bahariya well log correlation flattening on the top of the Lower Bahariya

\section{3- Structure model}

The Upper Bahariya, Lower Bahariya and Kharita depth maps are the main input for structural model (Fig. 12). The fault pillars were created by drawing manually a single polyline for up-thrown and downthrown sides to respect the structural geometry. A 3D model for the Shahd/ Shahd SE fields was built at a horizontal scale $(25 \times 25$ 2D layout) integrating all the geoscientific data. It contains three main lithological surfaces and nine faulted surfaces for a total of three closed geological bodies (regions/compartments) that creating a geo-cellular grid with a total number of defined cells of 2.5 million cells. The generated structural model using Corner point gridding technique in which we defined all 


\section{Geological 3D static model of Bahariya formation}

connection of the main faults with respect I and $\mathrm{J}$ directional trends to keep the cell angle below $70^{\circ}$, with no cell inside out and positive cell volumes with cell grid I increment 25 and $\mathrm{J}$ increment 25 (Fig. 13).

Each cell in the grid can be addressed by index (I, J) in two dimensions or (I, J, K) in three dimensions, and each vertex has coordinates $(\mathrm{I} \cdot \mathrm{dx}, \mathrm{J} \cdot \mathrm{dy})$ in $2 \mathrm{D}$ or $(\mathrm{I} \cdot \mathrm{dx}, \mathrm{J} \cdot \mathrm{dy}, \mathrm{K} \cdot \mathrm{dz})$ in $3 \mathrm{D}$ for some real numbers $\mathrm{dx}$, dy, and $\mathrm{dz}$ representing the grid spacing.

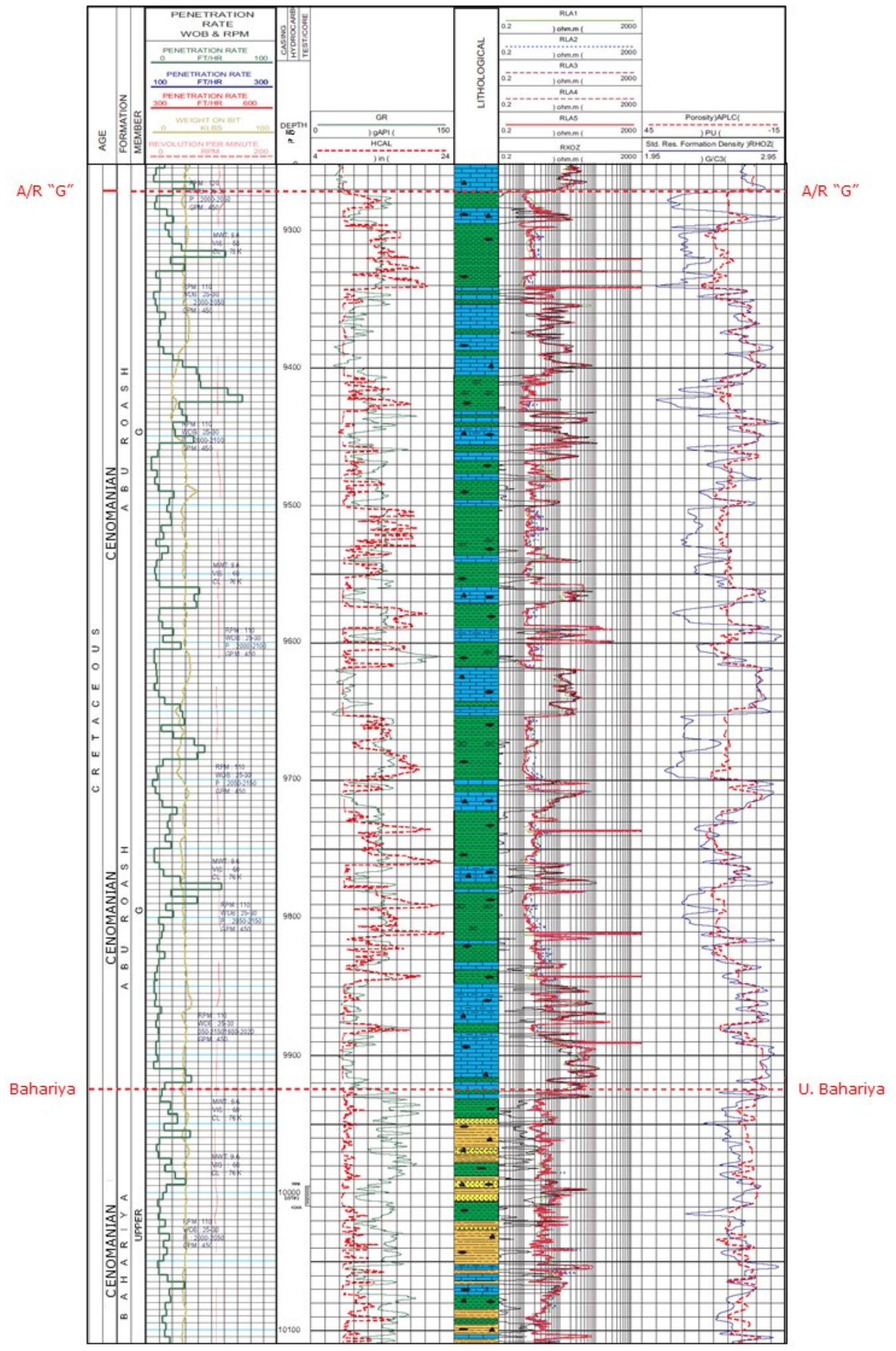


Mostafa et al.

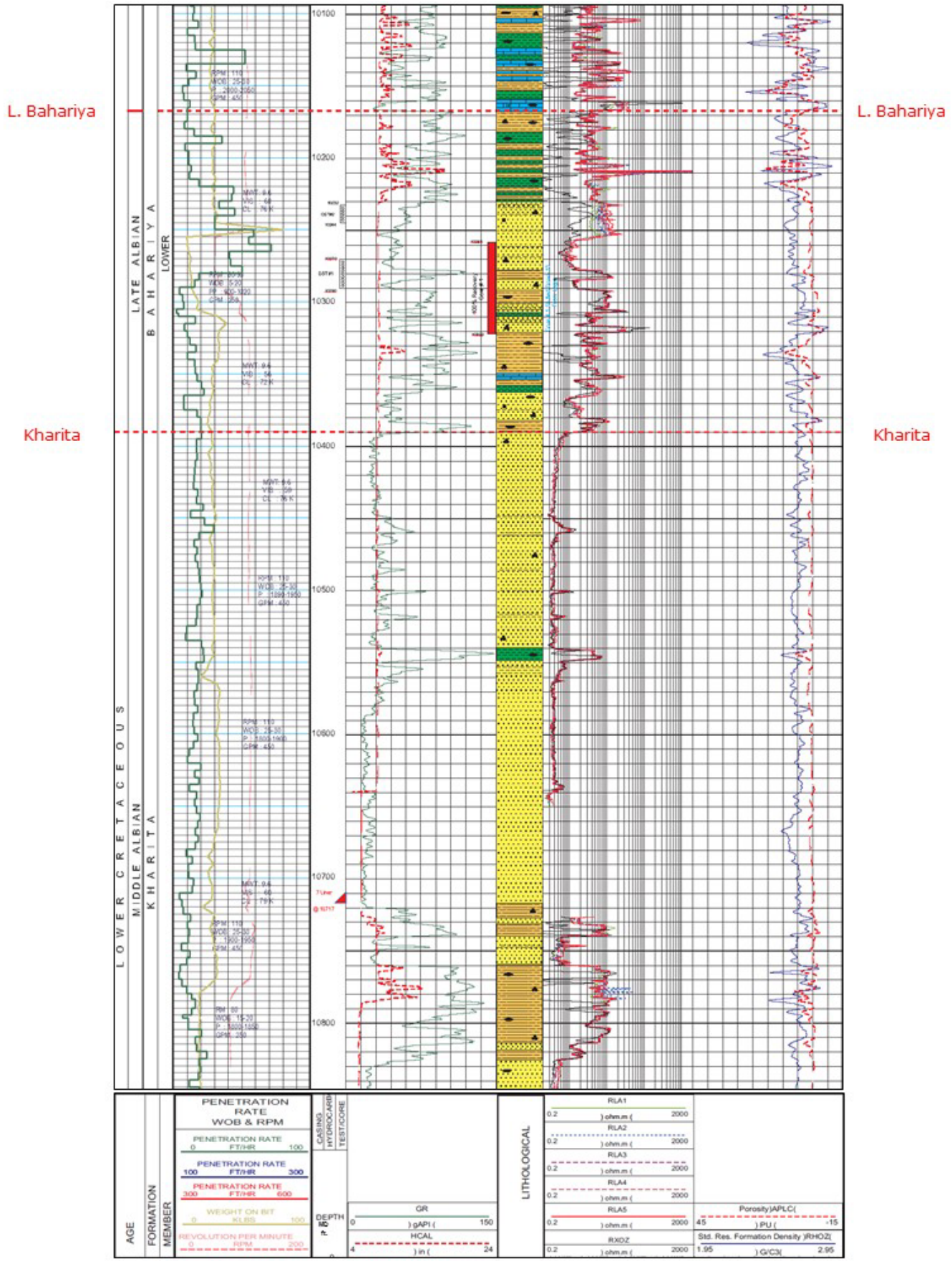

Fig. 11: Early Albian-Late Cenomanian (Kharita, Bahariya and A/R “G” Sections) Composite Type Log (Mostafa, 2016)

\section{4- Scaled up facies well logs and data analysis}

The scale up of well logs is an automatic process. When scaling up the well logs, software will first find the 3D grid cells that the wells penetrate. For each grid cell all log values that fall within the cell will be averaged according to the selected algorithm to produce one log value for that cell. The resulting 3D grid will only hold values for the 3D grid cells that the wells have penetrated.

Porosity logs were up-scaled to capture property values at cells along the well path (neighbor cells) after the 3D structural framework was created (Petrel, Schlumberger, 2015). 


\section{Geological 3D static model of Bahariya formation}

Fig. 12: 3D view of Upper, Lower Bahariya and Kharita Structural Model (Mostafa, 2016).
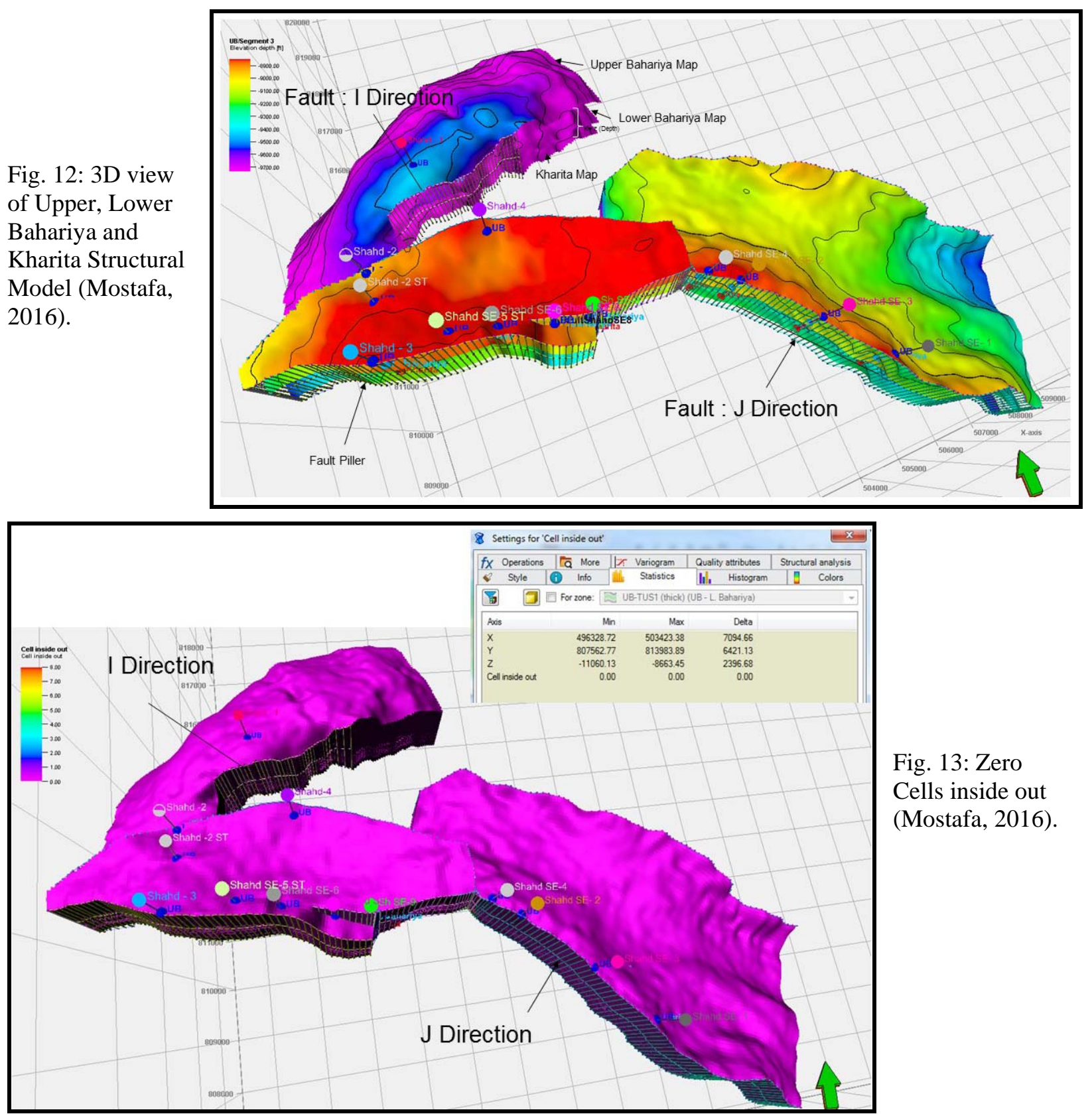

Fig. 13: Zero

Cells inside out

(Mostafa, 2016).

Facies logs of the used 13 wells were interpreted to identify three lithology types' non-reservoir and reservoir (sand shoals and tidal sand channels). The correlation panel was used to identify the extension of channels and to capture the communication between the wells across the field (Fig. 14). The correlation enables us to derive the reservoir characteristics for all zones and compute the fraction of each facies along the entire well path and in all zones.

Geostatistical analysis was done for each facies to identify the variogram major, minor, and vertical ranges plus the anisotropy of conceptual trends from the channel and bar interpretation. Figure 15 shows the NE-SW trend of the Tidal channel sand system which matches with the regional conceptual model (Fig. 8). The isopach map shows the same axial direction.

Total sand Isopach maps of the main 3 stacked tidal channel showed the same variogram direction which is perpendicular to the NW-SE Cretaceous fault trend (Fig. 16). 
Mostafa et al.

Fig. 14: 3D view of Bahariya upscaled porosity
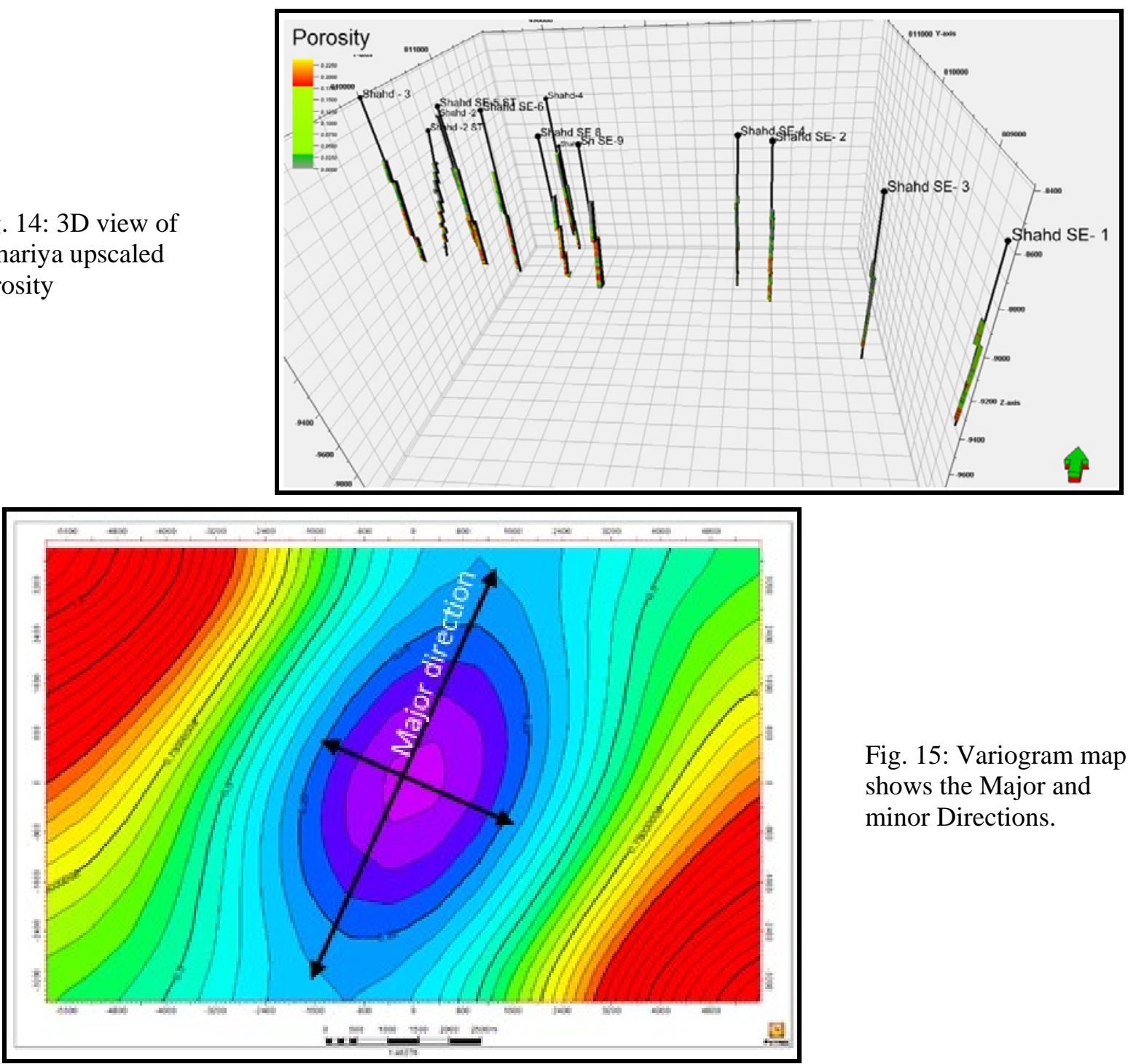

Fig. 15: Variogram map shows the Major and minor Directions.

Fig. 16: Khatatba

Formation Gross Isopach Map (Present Study)

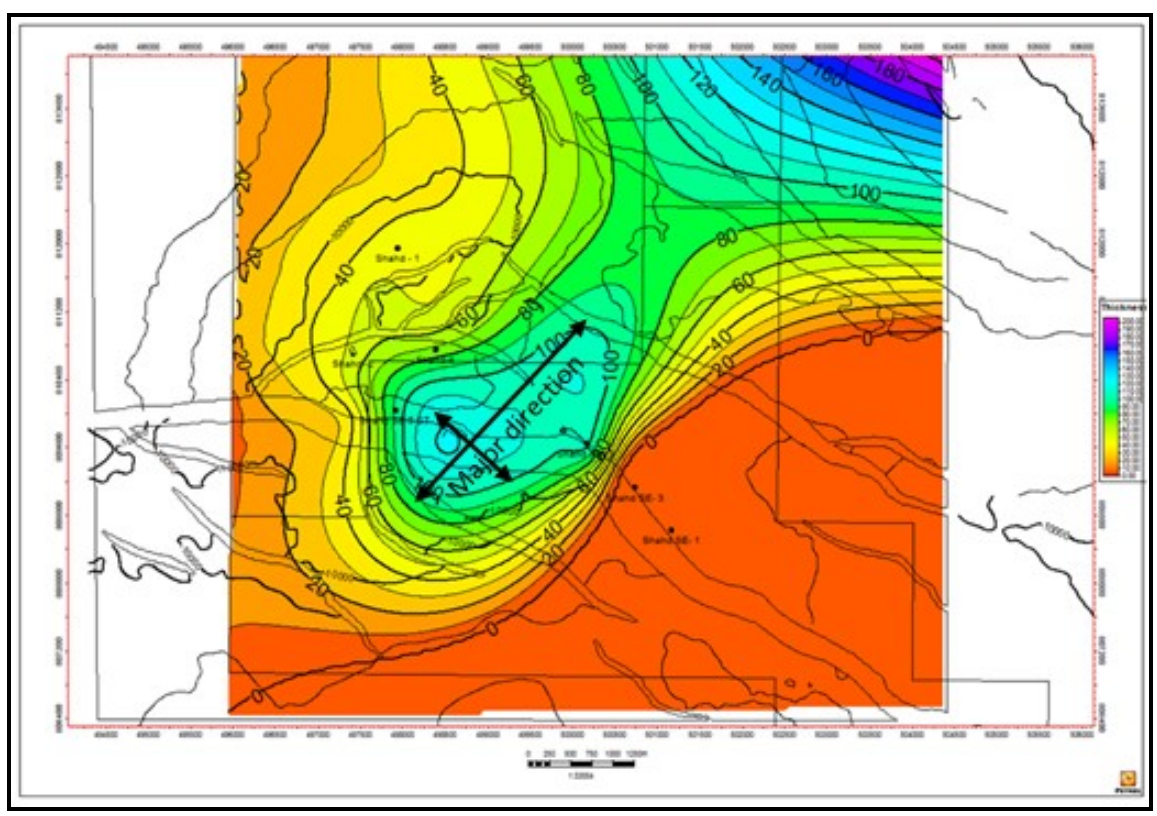




\section{Geological 3D static model of Bahariya formation HIERARCHICAL FACIES MODEL}

The sediments encountered have been interpreted from core data as being deposited in a tide-dominated environment. The identified stacked sandstone units, most likely, represent tidal channel and bar deposits showing moderate to good reservoir qualities. The probability maps are generated from the raw well data for each zone in the 13 selected wells (Figs. 12-16).

The identified facies (sand channel good reservoir, sand shoal bad reservoir, and mudstone nonreservoir) confirmed the conceptual depositional anisotropy that matching the core data analysis (Fig. 7). A horizontal variogram was generated for each zone to determine the major direction, minor direction, and heading angle (anisotropy of depositional environment) to be a main input for executing the sequential indicator simulation for facies model. This approach is employed to generate a range of distribution comprising sets of quantitative information on proportions, geometries, and spatial relations that be used for conditioning the petrophysical model.

A pixel-based model generated by sequential indicator simulation (SIS) for facies distribution for each zone (includes horizontal variogram and 2D trends to fit the conceptual model) enables the generation of extremely realistic geological models (Fig. 17), related to all available geophysical data, wireline logs and core data.

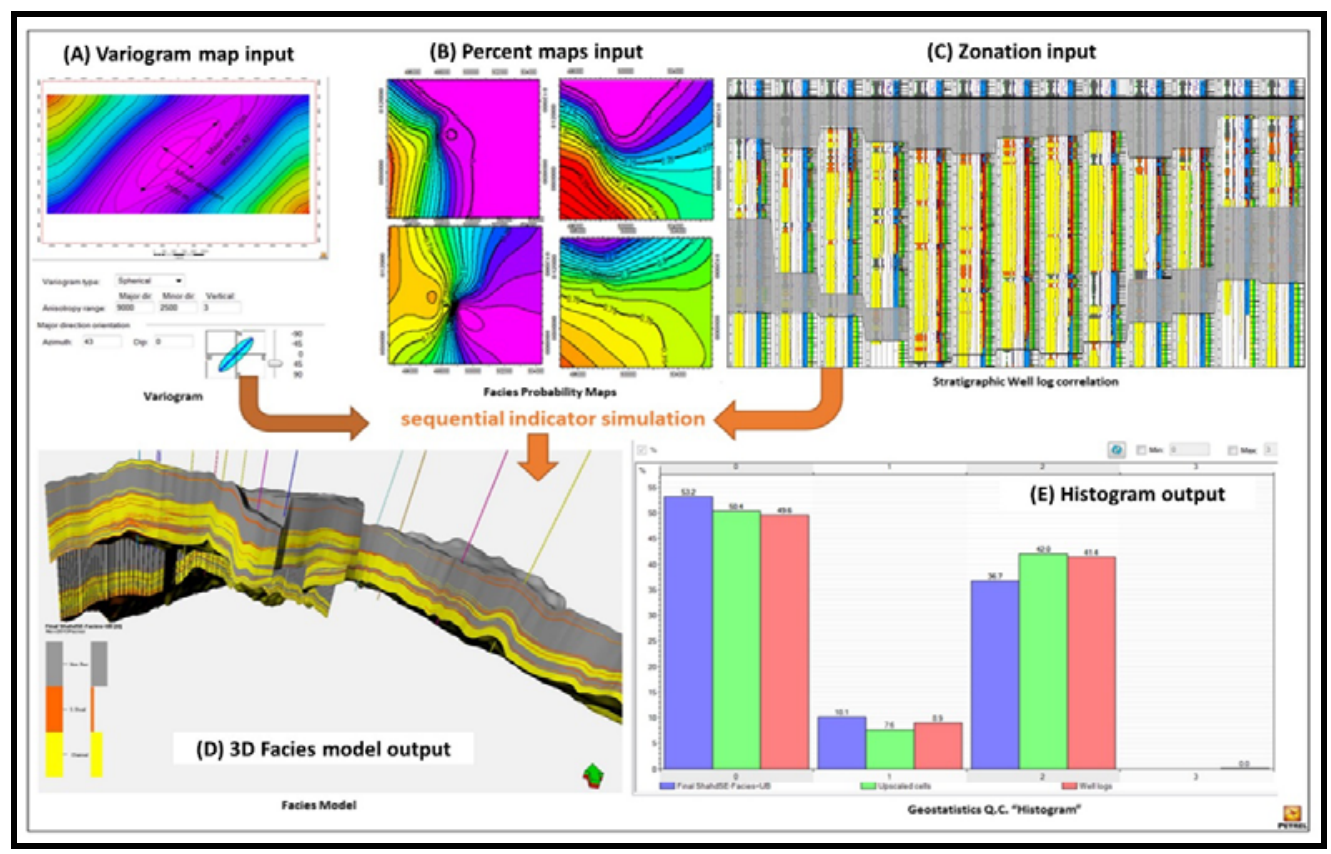

Fig. 17: Facies

Model and

Probability Map

\section{PETROPHYSICAL MODELING}

This modelling stage is extremely important because it defines the porosity quality and the quantity of hydrocarbons entrapped in the reservoir. The measured porosity on rock samples of linear dimensions (limited to $1 \times 1.5$ inches), using techniques that involve the extraction of fluids, or, vice-versa, the introduction of fluids into the sample's porous system are applied. The stochastic petrophysical modeling used sequential Gaussian simulation (GSLIB) biased by facies distribution (Fig. 18), in which well data were honored, petrophysical data transformation (porosity), variogram, and trends. Local variations away from input data were created using the variogram and distribution.

The widely used stochastic GSLIB method is based on kriging by which we can honor input data distributions, variogram, and trends, using Petrel software (Schlumberger, 2015).

Limited log data input for a particular property makes it challenging to fit the histogram based on statistics derived from neighboring fields or the literature, so the mean and standard deviation values will be used to distribute that property using Sequential Gaussian Simulation (SGS) modeling based on the 
Mostafa et al.

conceptual model. In case there are some data, the estimated mean and standard deviation from the data given will help to get better resolution based on the property cutoff, as shown in (Fig. 19).

Fig. 18: 3D Facies model (Mostafa, 2016)
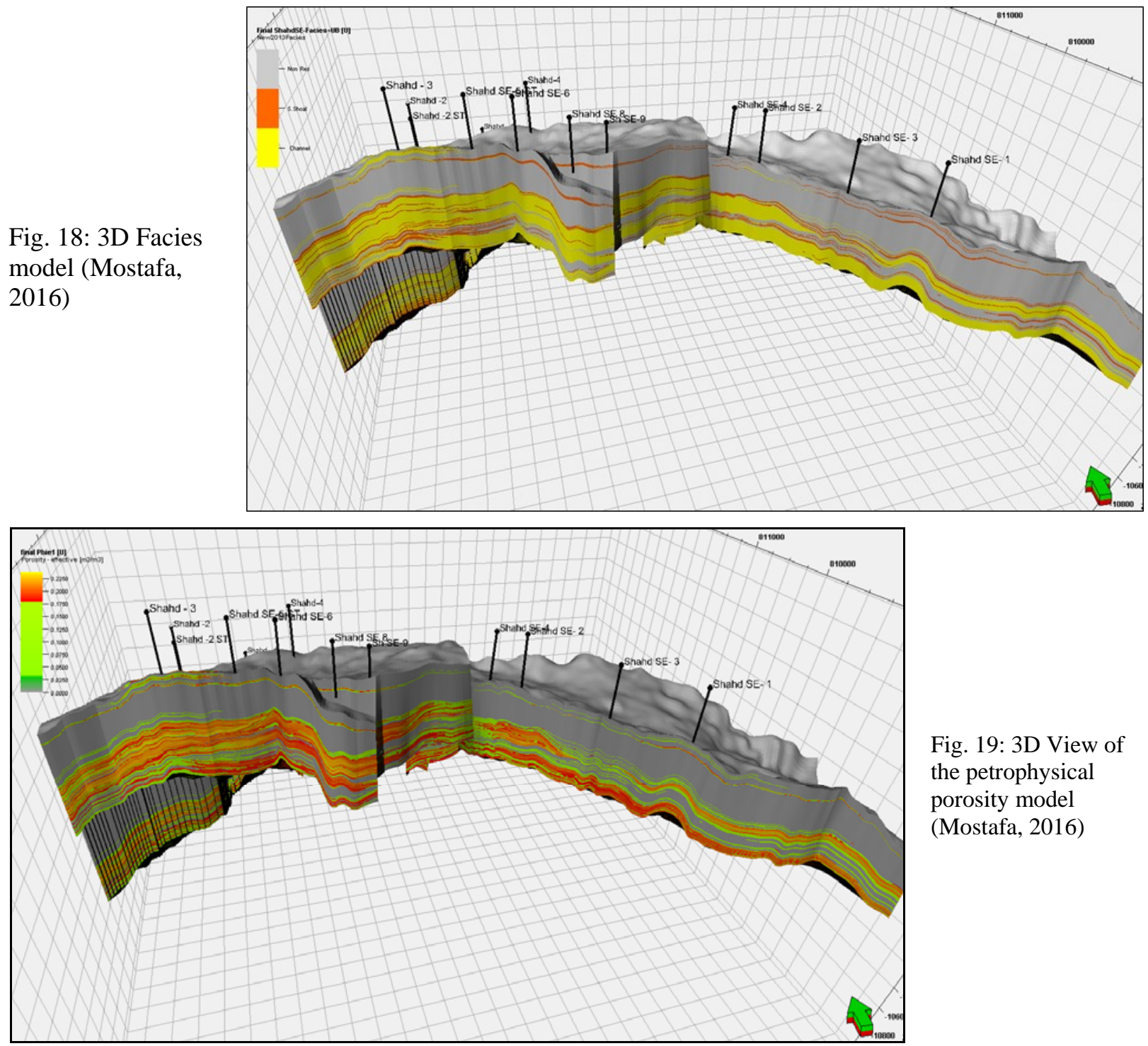

Fig. 19: 3D View of the petrophysical porosity model (Mostafa, 2016)

\section{SUMMARY AND CONCLUSIONS}

1. The encouraging oil discoveries in East Tiba sub-Basin gave the initiatives for study the Cenomanian/Late Albian Lower Bahariya geological system.

2. The structural evaluation of the East Tiba in the context of the regional North Western Desert province indicated the presence of multi-phases tectonic history

3. The Bahariya Formation has been dated as Late Albian-Early Cenomanian age and was divided into Lower \& Upper Bahariya Members.

4. The interpretations of the Lower Bahariya conventional cores, sedimentary structure and floral contents indicated that the Lower Bahariya member has been deposited in the marginal marine possible tidaldominated estuary.

5. The biostratigraphic results indicated that there is no considerable sedimentation break during the Upper Albian Lower Bahariya systems and the depositional setting was possible continued till the Upper Bahariya member of proper Early Cenomanian age. 


\section{Geological 3D static model of Bahariya formation}

6. A 3D reprocessed seismic PSDM (Pre-Stack Depth Migration) cube have been used in addition to the well data to produce the Bahariya structural map as it represents a good seismic marker allover the study area.

7. The structural play concept is mainly represented by a three-way dip closures along northwest trending Cretaceous faults with enough throws $( \pm 600$ ') to bring the Abu Roash " $G$ " shales juxtaposing the Lower Bahariya sandstone reservoir.

8. There is three main property types of non-reservoir, poor reservoir and good reservoir facies type (mudstones and sandstones)

9. Constructing the hydrocarbon 3D reservoir model based on the applied integrated workflow demonstrated the validity of the static model to be used as a fundamental base for the dynamic model.

\section{ACKNOWLEDGEMENTS}

The authors would like to thank PetroShahd Company and their partners, Egyptian General Petroleum Corporation (EGPC), Enap Sipetrol and Kuwait Energy Companies for permission to use and publish this material.

And special Thanks to my colleges at Sipetrol for continues support and to my lovely family.

\section{REFERENCES}

Abdel kireem, R. M., Schrank, E., Samir, E. and Ibrahim, A. I. M., (1996): Cretaceous Paleoecology, Paleogeography and Paleoclimatology of the Northern Western Desert, Egypt, Review J. Afr. Earth Sci., 22 (1), 93-112.

Ball and Beadnell, (1903): Bahariya Oasis, its topography and geology: Survey Department, Cairo, p. 84.

Barakat, M., Darwish, M., and Abdel Hamid, M. L., (1987): Hydrocarbon source rock evaluation of the Upper Cretaceous (Abu Roash Formation) east Abu Gharadig area, North Western Desert, Egypt. Ain Shams Univ., Earth Sci., J. 1:120-150.

Blanckenhorn, M., (1921): Handbuch der regionalen Geologie. Bd. V11, Abt.9, Heft 23, Aegypten. Carl Winters Universitat sbuchhandlung, Heidelberg, 24 H P.

Darwish, M. (1994): Sedimentary, environmental conditions and hydrocarbon habitat of the Bahariya Formation, Central Abu Gharadig Basin, Western Desert, Egypt. Proc. 12 ${ }^{\text {th }}$ E.G.P.C. Petroleum Exploration and Production· Conference, Cairo, 1, 429-449.

Darwish, M. and Tawfik, N., (2008): Sequence stratigraphy and facies of the Jurassic-Lower Cretaceous rift system in NE Africa. Geology of East Libya, 1, 345-368.

Dolson, J. C.; Shann, M. V.; Hammouda, H., Rashed, R. and Matbouly, S. (2000): Egypt in the twentyfirst century: petroleum potential in offshore trends: GEOARABIA, 6, 211-229.

Dominik, (1985): Stratigraphie und Sedimentologie (Geochemie, Schwermineralanayse) der Oberkreide von Bahariya und ihre korrelation zum Dakhla Becken, (Western Desert, Agypten). Berl. Geowiss. Abh. 50 (A) 153-176.

Geizery, (1998): Qarun field geological model and reservoir characterization: a successful case from the Western Desert, in M. Eloui, ed., Proceedings of the $14^{\text {th }}$ Petroleum Conf., Cairo, Egypt, The Egyptian General Petroleum Corporation, 279-297.

Hegazy, (1992): Western Desert, Oil and Gas Fields (A Comprehensive Overview), Cairo, Egypt, The Egyptian General Petroleum Corporation, p. 431.

Keeley and Massoud, (1998): Tectonic controls on the petroleum geology of NE Africa, in D. S. MacGregor, R. T. J. Moody, and D. D. Clark-Lowes, eds., Petroleum Geology of North Africa: Special Publication No. 132, London, Unite Kingdom, Geological Society, 69-78.

Lebling, (1919): Ergebnisse der Forschungsreisen Prof. E. Stroners in den Wusten Aegyptens: Teil III, Forschungen in der Bahariya Oase und anderern Gegenden Aegyptens.: Abh. Bayer Akad Wiss Math. Naturw, 29.

Mahmoud, A. and Barkooky, A. N., (1998): Mesozoic valley fills incised in Paleozoic rocks: potential exploration targets in the North Western Desert of Egypt, Obaiyed area, in M. Eloui, ed., Proceedings of the 14th Petroleum Conference, Cairo, Egypt, The Egyptian General Petroleum Corporation, 84100. 
Mostafa et al.

Moustafa, A. R., Badrawy, R. E. and Gibali, H., (1998): Pervasive E-ENE oriented faults in Northern Egypt and their effect on the development and inversion of prolific sedimentary basins, in M. Eloui, ed., 14th Petroleum Conference, Cairo, Egypt, The Egyptian General Petroleum Corporation, p. 51-67.

Nemec, M. C., (1996): Qarun oil field, Western Desert: Proceedings of the $13^{\text {th }}$ Egyptian Petroleum Conference, 1, 140-165.

Norton (1967): Rock Stratigraphic Nomenclature of the Western Desert. Internal Report, Pan- American U.A.R. Oil Company (now AMOCO), Cairo, 18pp.

Said, R. (1990): Cenozoic, in R. Said, ed., The Geology of Egypt, Rotterdam, Netherlands, A. A. Balkema Publishers, p. 451-486.

Sestini, (1984): Tectonic and sedimentary history of the NE African margin (Egypt-Libya), in J. E. Dixon, and A. H. F. Robertson, eds., The Geological Evolution of the Eastern Mediterranean: Special Publication No. I 7, London, United Kingdom, the Geological Society, 161-176.

Stromer (1914): Ergebnisse der-Forschurigsreisen Prof. E. Stromers in den Wusten Agyptens. II.Wirbeltier Reste der Baharije-Stufe (unterstes Cenoman), 1. Einleitung und 2. Libyconsuchus. -Abh, bayr. Akad, Wiss., math-phys. Kl, 27(3): 16p.

Schlumberger, (1984): Well Evaluation Conference, Egypt. Schlumberger Middle East, S. A: 9-18.

Schlumberger (1990): Generalized litho-stratigraphic column of northern Western Desert, Egypt.

Taha, M., (1992): Mesozoic rift basins in Egypt: their southern extension and impact on future exploration, $11^{\text {th }}$ E.G.P.C. Petroleum Exploration and Production· Conference, Cairo, Egypt, 2, 1-19.

Tassy, A., Crouzy, E., Gorini, C., Rubino, J., Bouroullec, J. and Sapin, F., (2015): Egyptian Tythyan margin in the Mesozoic: Evaluation of a mixed carbonate-silisiclastic shelf edge (from Western Desert to Sinai). Marine and Petroleum Geology. 1-17.

Un-published Internal Reports:

Corex Company, (2012): Shahd SE-5 well core report.

Geocomp, (2007): Biostratigraphic data summary of Bahariya and Kharita formations of Shahd-1 Well.

Mostafa, M.M., and Fahmy, M., (2015): Regional conceptual depositional model of Lower Bahariya Reservoir in East Tiba Sub-Basin, northern Western Desert, Egypt.

Mostafa, M.M., and Fahmy, M., (2016): Shahd/Shahd SE well log correlation, East Tiba Sub-Basin, northern Western Desert, Egypt.

Schlumberger, (2015): Petrel Software Manual. 


\section{Geological 3D static model of Bahariya formation}

بناء نموذج جيولوجى ثلاثى الابعاد لتكوين البحرية لعصر (الألبي العلوي - العينوميني) في حقول شهد - شهد جنوب شرق

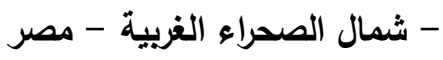

محمود محمد مصطفي' و محمد محمود فهمي' و محمد درويش

شركة إيناب سيبترول-مصر ' قسم الجيولوجيا-كلية العلوم-جامعة القاهرة'

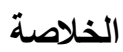

لقد أدى إكتثاف النفط إقتصاديا لأول مرة فى عام ه . . من طبقة رمال تكوين البحرية السفلي - عصر الألبى المتأخر

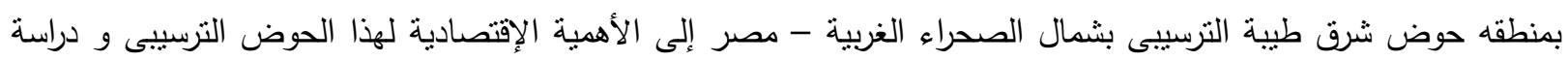
تتابعاته الجيولوجية.

إثتملت الدراسة على التقييم الجيولوجي لخزان البحرية السفلى الحامل للزيت الخام باستخدام التسجيلات الكهبائية والسحنات

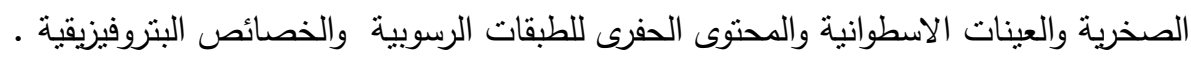

وأوضحت الدراسة أن رمال خزان البحرية السفلى يتبع عصر الألبى المتأخر والذى سادت بيئة بحرية ضحلة فى منطقة المد

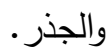

ولقد تم بناء نموذج عام للبيئة الترسيبية لهذه الصخور كخلجان شاطئية مشتملة على رواسب رملية متتابعه ليشمل مناطق

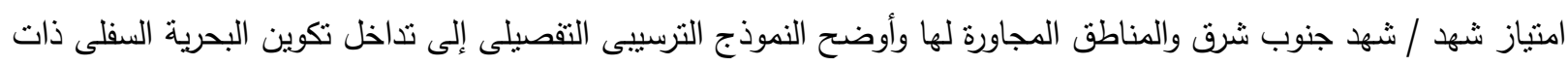

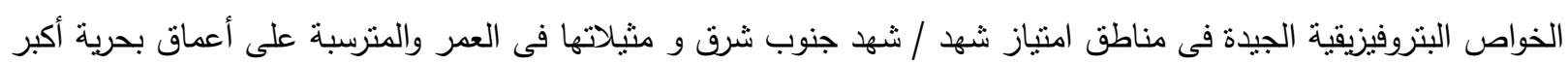
وذات خواص بتروفيزيقية و إنتاجية أقل.

إثتملت الدراسة على التفسيرات السيزمية ثلاثية الابعاد وإستخدام البيانات المتاحة للآبار فى حوض شرق طيبة الفرعى والتى أوضحت شكل وحدود الحوض الترسيبى الحامل للزيت الخام والفوالق الدصاحبة له فى وقت ترسيب تكوين البحرية السفلى. كما إثتملت الدراسة على بناء نموذج جيولوجي أستاتيكى ثلاثى الأبعاد لتكوين البحرية السفلى والذي يعد كمدخل أساسى

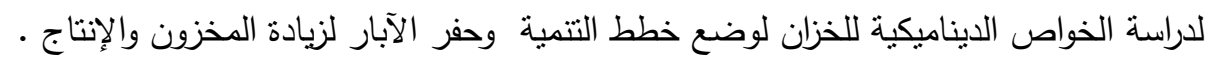

